\title{
An Analysis of Students' Cultural Intelligence: A Case Study at the State Junior High School (SMP N) 20 of Surakarta
}

Vidia Ulfa Mareta ${ }^{1}$, Sunardi ${ }^{2}$, Suharno ${ }^{3}$

\section{ARTICLE INFO}

Article History:

Received 04.09.2018

Received in revised form

22.11.2018

Accepted

Available online 01.01.2019

\begin{abstract}
Human behavior naturally produces culture. Each group has a unique culture and is diffe rent from one another. The digital age allows an increasingly unlimited distribution of culture. Like wise, cross-cultural interactions will be increasingly carried out by each individual. It is important for students to understand cross-cultural interactions with their cultural intelligence. As an effort to multiply social relations and identify effective behaviors at the time the cross-cultural interactions occur. This study used descriptive quantitative methods. The research instrument applied questionnaires. The population in this study were all students of VII grade in the State Junior High School (SMP N) 20 of Surakarta. The Sampling technique used simple random sampling which took 89 participants. The data collection techniques applied the technique of survey. The components of cultural intelligence cover among others;the CImetacognitive, CI cognitive, CImotivation, CIbehavior. The percentage results of the metaCI cognitive showed $64.77 \%$, the CI cognitive showed $62.88 \%$, the CI motivation showed $64.81 \%$ and CI behavior showed $60 \%$.
\end{abstract}

(C) IJERE. All rights reserved

Keywords:

Culture, cross culture, cultural intelligence.

\section{INTRODUCTION}

\section{Introduction}

In effectively use their minds, humans can develop various kinds of actions. This shows that human behavior always produces culture (Koentjaraningrat, 2009). Each ethnic group has a different culture from other ethnic groups and proves that one tribe over the other civilization produces knowledge, foundations of thought and history of civilization share differences one another (Budiono, 2008). Culture may not onlu in art form, it can be tangible, namely: language, technological systems, livelihood systems, social organizations, knowledge systems, religion, arts (Zuchdi, 2008). The role of education is fundamental to cultural diversity. In itstransmission process it is the underlying determinant of thestudents' attitude in confronting various cultures (Mareta, 2018).

The importance of mutual respect for students in their cultural heterogeneity is part of cultural intelligence (Dana, 2018). For that reason, cultural intelligence plays a significant role in building relationships and maintaining social relationships, which are in line with cross-cultural needs in the future (Arlita).

Cultural intelligence is the ability of individuals to understand, think, and behave effectively in a variety of cross-cultural situations (Widyarini, 2014). This opinion shows that cultural intelligence is part of the interpersonal intelligence. This is because cultural intelligence is part of an individual's intelligence in interacting with other people with different cultural backgrounds. Early and Ang (2003) described cultural intelligence as a complex individual attribute and various components (Ang, p. 2011). Ang, et al. (2014) revealed that cultural intelligence is synonymous with social intelligence and emotional intel ligence. Although it remains identical and shares differences, where social intelligence refers to a person's ability to understand and manage social relationships with others. Meanwhile, emotional intelligence is more on the individual's ability to manage emotions themselves and others. Whereas cultural intelligence is more emphasized on managing oneself and others in an intercultural context (Suharli, 2017). Through cultural intelligence, it allows individuals to be able to identify how other people think and how different behaviors occur. The results of cultural intelligence allow individuals to have the ability to organize activities effectively both in certain fields and other cultural aspects including behavior, stimulation, cognitive and

1vidiaulfa4@gmail.com, Sebelas Maret University², orcid.org/0000-0001-9072-7921 
metacognitive components applying in decision making, according to culture (Ang et al., 2007). It is clear that the components of cultural intelligence include four things: metacognitive (strategy), knowledge (cognitive), motivation and behavior.

The components constituting cultural intelligence are CQ- strategy, CQ- knowledge, CQmotivation, CQ- behavior. The four components were revealed by Linn (2016), who classified the four factors of cultural intelligence. These four factors are inter related in using to analyze the level of cultural intelligence of students. Some dimensions of cultural intelligence are more dynamic and not static, how ever, they can be improved through training, experience, and education (Suciani, 2017). Therefore, this study aims to determine the students' cultural intelligence.

This study specifically examines students of junior high school (SMP). The students of SMP were chosen as the object of this study since during the age they tend to explore more outside culture. This is evidenced by the existence of festival events that uphold foreign culture. Thus this study examines the cultural intelligence of junior high school students in SMP N 20 of Sur akarta.

\section{Research Method}

The study was conducted in the State Junior High School (SMP N) 20 of Surakarta, in the odd semester of the 2018/2019 academic year, precisely in September 2018. The population in this study were all VII grade students in the StateSMP 20 of Surakarta, while the sample was chosen randomly (simple random sampling) of 89 students. The age range of the sample was between 13 to15 years old. The samples were divided into 59 men and 30 women, all the subjects varied according to various economic backgrounds, as well as school culture at the elementary school. Specifically, the subjects were students who have passed the Social Sciences subject on the chapter of inter-space interactions exploring various cultures in Indonesia. This study was analyzed descriptively, which all data either obtained in the form of numbers or non, will be inter preted descriptively. The method used is the survey method. According to Sukardi (2009) technically, survey research refers to technically obtaining data in research activities by using questionnaires or questionnaires. The instrument used in measuring the cultural intelligence of students in this study was a questionnaire. The questionnaire chosen refers to the cultural intelligence parameters adapted from the 2016 Cultural Ontelligence Center which has been adjusted for students in junior high school on a scale of 1 to 5 .

The data analysis questionnaire is, therefore, arranged througha set of value scalesranging from 1 to 5. The following measure indicates scales use in this study, among others; $1=$ very less, $2=$ less, $3=$ enough, 4 = good, 5 = very good. While for the interpretation criteria of students questionnaire assessment scores follows Arikunto's model (Arikunto, 2007), as seen in Table 1 below.

Table 1. Criteria for Evaluating the Percentage of Cultural Intelligence Questionnaire

\begin{tabular}{|c|c|c|}
\hline \multicolumn{2}{|c|}{ Values } & \multirow{2}{*}{ Categories } \\
\hline Numbers & Letters & \\
\hline $81 \%-100 \%$ & A & Excellent \\
\hline $61 \%-80 \%$ & $\bar{B}$ & Good \\
\hline $41 \%-60 \%$ & $\mathrm{C}$ & Enough \\
\hline $21 \%-40 \%$ & $\mathrm{D}$ & Less \\
\hline $0 \%-20 \%$ & $E$ & Very Less \\
\hline
\end{tabular}

\section{Results and Discussion \\ Results}

The research results were presented in the form of tables and graphs. The use of tables was intended to concretely see the data. Meanwhile, data presentation was in graphs, which aims to simplify the data results presentation in a diagram form. The presented aspects cover four components of cultural intelligence, 
among others: CI- strategy, CI- knowledge, CI- motivation, CI- behavior. The results of the students data described in below graph.

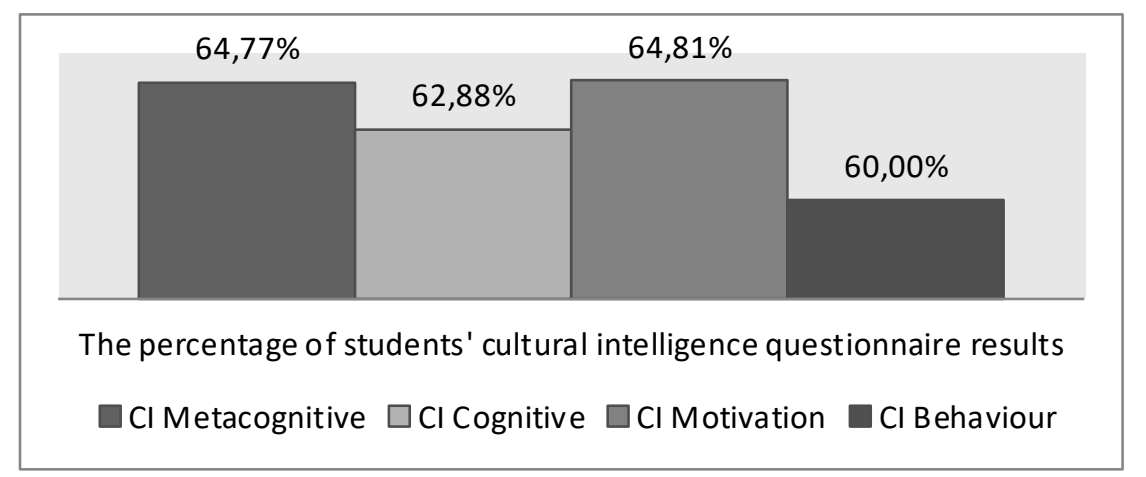

Figure 1 . The percentage of students' cultural intelligence questionnaire results.

More details about thecultural intelligence results of junior high school students in a case study at SMP N 20 of Surakarta describes in the following table.

Table 2. The Percentage of Cultural Intelligence Questionnaire Results.

\begin{tabular}{|c|c|c|}
\hline Components & Components & Components \\
\hline CI Motivation & CI Motivation & CI Motivation \\
\hline CI Cognitive & CI Cognitive & CI Cognitive \\
\hline CI Motivation & CI Motivation & CI Motivation \\
\hline CI Behavior & CI Behavior & CI Behavior \\
\hline
\end{tabular}

Based on the above table, the percentage value of the cultural intelligence of students VII grade on the metaCI cognitive component was $64.77 \%$. The results wereclassified into Good, which means that students' consciousness in setting strategies, enables them to behave effectively in cross-cultural coverage. The second component of the CI cognitive aspect. Being part of the sustaining element which allows subjects to be able to adjust across cultures. Students need to have knowledge of other cultures. In the chart above the percentage value of CI Cognitive is $62.88 \%$, meaning that students of VIIgradeshare theGood cross-cultural knowledge.

The third component is CIMotivation. This component reflects the highest value compared to other components. In this result, the CI motivation component value was $64.81 \%$. This value shows the Good criteria. The last component of $\mathrm{CI}$ behavior obtained the low est percentage value, which is $60 \%$. This value is found in the third level which is notified as letter $\mathrm{C}$ and marked the Enough category.

\section{Discussion}

Cross-cultural relationhiphas been increasingly happening. The existence of industrial revolution 4.0 leads every human activity intersects with other cultures. Cultural intelligence is a part of social skills that a person shouldownin encountering the digital era. Cultural intelligence is the individuals' ability to behave effectively in cross-cultural communication (Suharli, 2017). The individual's activityin feeling and realizing he is in a different cultural situation at general point. Early and Ang (2003) suggest that having a good interaction relationship and leading to positive action will result in a well-cooperation. Therefore, having intelligence is quite pivotal for students, especially for those who are in their teens. This reinforces the notion that cultural intelligence enables one to identify and understand each other in behaving and acting with different cultures.

Another positive side of cultural intelligence is that it allowsstudents to be able to adapt in a new environment. Every motivation value is projected to understand new culture is high, then other adjustments remains high too (Dana, 2018). In this study the highest value is found in the CI motivation, thus, the other values share similarity, which is between the Good and Enough categories. This shows that each component between CI metacognitive, CI cognitive, CI motivation and, CI behavior has a related relationship. 
Mareta,V.U, Sunardi \& Suharno (2018). An analy sis of students' cultural intelligence : A case study at the state junior high school (SMP N) 20 of Surakarta. International Journal of Educational Research Review,4(1),76-81.

Although Thomas et.al (2018) also reveals simpler components of cultural intelligence, namely cultural knowledge, cultural metacognition, and cross-cultural skills. In this study it is more inclined to Ang's intelligence components (Dana, 2018).

The following is the concept of Ang's cultural intelligence (2003):

\begin{tabular}{cl}
\hline Cognitive & $\begin{array}{l}\text { General knowledge enables individuals to be able to interpret new cultures is part of } \\
\text { cross-cultural }\end{array}$ \\
\hline Metacognitive & $\begin{array}{l}\text { Mental to understand and acknoledge experiences in interacting with individuals } \\
\text { across cultures }\end{array}$ \\
\hline Behavior & $\begin{array}{l}\text { Ability to adapt and use skills in actions so that individuals can be accepted in new } \\
\text { cultures }\end{array}$ \\
\hline Motivation & $\begin{array}{l}\text { Having motivated in using cultural knowledge to interact with individuals across } \\
\text { cultures }\end{array}$ \\
\hline
\end{tabular}

This study was conducted quantitatively, which applied a randomized ques tionnaire about cultural intelligence to VII grade students. Based on the results of the analysis obtained in the initial segment, CI metacognitive showed $64.77 \%$, CI cognitive with $62.88 \%$. Meanwhile, each of the CI Motivation and CI Behavior came with the results of $64.81 \%$. and $60 \%$. The average category of each component classified as the Good value.

CI Metacognitive is the intelligence and aw areness on interacting with other people across cultures. There are three basic reasons for triggers, first, the tendency to encourage active thinking about people with different cultures. Second, encourage more critical habits, assumptions, and cultural thinking related to interaction partners. Third, it allows individuals to reflect on the accuracy of their underst anding (Ang, 2008).

On the results of the CI value metacognitive showed the second highest percentage value which concludes that students of grade VII is at theGood category. This shows that their mental attitude to regulate knowledge, attitudes and motivation, effectively in a cross-cultural manner is good. It can be concluded that class VII students can strategize when they interact with cross-cultural interlocutors.

CI cognitive is a knowledge of one's culture that can be implemented in cross-cultural interactions (ang et., 2007). CI cognitive is very important because it is related to one's decision making in cross-cultural interactions. The higher the value of a person's cultural intelligence cognitive shall make it easier to understand the dynamics of a cross cultural interactions (Suciani, 2017).

The results of the CI cognitive percentage show the Good category. This means that, other cultural knowledge of students VII grade in SMP N 20 of Surakarta is at the Good category, thus students' cognitive cultural intelligence components can be implemented properly when interacting across cultures. This is highly beneficial for students for it facilitates them on interacting and making decisions.

CI Motivation is the individuals' motivation in part of optimizing their attention to cultural differences (Dyne, 2016). It is personal ability in a more detail understanding about different cultures. Students' high curiosity about the culture of other s 'cross-culture' includes driving factors in the percentage value of cultural intelligence motivation.

The results of $\mathrm{CI}$ motivation value percentage was $64.81 \%$ whichis atthe Good category. This value is the highest percentage compared to the other valuesof component percentages. The students' motivation to know in more detail about different cultures is shown by interactions of students VII grade of SMP N 20 of Surakarta classified as the Good category. The development of technology increases students' ability in adapting to their external environment across cultures.

CI behavior concerns the individual's ability which is indicated through verbal and nonverbal actions that are appropriate in interacting with people of different cultural backgrounds. Among other 
components, cultural intelligence is the most important component because it appears to the eye. Individuals with high behavioral cultural intelligence can adjust their behavior through cross-cultural interaction.

On the percentage results for $\mathrm{CI}$ behavior showed $60 \%$ and classifiedinto the Enough category. This is the lowest value compared to the other values. In this case, the students' ability in engaging with both verbal and nonverbal actions at cross-cultural interactions is, therefore, categorized into the Enough category. Although the percentage value of CI cognitive shows the highest value, it does not affect CI behavior. Where students' skills are not in line with their knowledge. This shows that CI behavior develops a bit slower than other components. Of course this also happens because behavioral synergy requires daily habituation.

The higher a person's cultural intelligence, the more they are able to appreciate cross-cultural differences. Many efforts have been made especially in increasing the cultural intelligence. One of the ways to remember cultural intelligence can be done by increasing cross-cultural interactions, cross-cultural experiences, trying to deepen in understanding other different cultures.

Various cross-cultural activities today are quite easy for the community to do. Moreover, the idea of connectedness between individuals and telecommunications equipment makes it easy to interact across cultures. This opens up opportunities for individuals to exchange opinions with those who have different cultures and can also increase cultural intelligence. Reading various literature about other cultures is also another way to increase cross-cultural experience. Increasing cultural intelligence can also be done in the academic field, i.e., integrating subjects with developing cultures. Integration can, therefore, be realized on learning models, learning media or teaching materials used. Being open to understanding and $w$ ishing to learn about other cultures is the key to increasing cultural intelligence (Roy, 2018). On the other hand differences between individuals and concepts, cause the individual cannot control his behavior (Hadi Warsito., 2018). Therefore, it is most important for students or other people to understand culture and other people using it.

\section{Conclusion}

Cultural intelligence is at least divided into four major components, namely the CI Metacognitive, CI Cognitive, CI Motivation, CI behavior. The results of the study on the research subjects, namely grade VII students of SMP N 20 of Surakarta showed that the Enoughor average percentage value in terms of the cultural intelligence, which is at the Good category. Although the CI behavior received the lowest score compared to the other percentage values. The students' cultural intelligence, is therefore, classified into Good category. This is because there w as no significant difference found in the percentage value between the metacognitive motivation, CI cognitive, CI motivation, and CI behavior. This study is limited to the research subjects who were involved,they were students of elementary level, and was conducted in the local area. Consequently, thestudydoes not intentionally generalized overall state of the junior high school students' cultural intelligence. One's regional area to another may be found vary depending on the students' cross cultural experience conditions that they have.

\section{References}

Ang, S. L. (2011). Cultural intelligence. In R. J. Kaufman, The Cambridge Handbook of intelligence (pp. 582-602). Cambridge: Cambridge University Press.

Arikunto, S. (2007). Manajeemen penelitian. Jakarta: Rineka CIpta.

Arlita, D. A. (n.d.). Indonesiabaik.id/infografis/keterampilan-untuk-hadapi-revolusi-industri-40 . 10/2018 Retrieved September 1, 2018,

Budiono. (2008). Simbolisme Jawa. Yogyakarta: Ombak. 
Mareta,V.U, Sunardi \& Suharno (2018). An analy sis of students' cultural intelligence : A case study at the state junior high school (SMP N) 20 of Surakarta. International Journal of Educational Research Review,4(1),76-81.

Dana, L. O. (2018). Cultural intelligence: A review an New Research avenues. International Journal and management, 99-119.

Dyne, L. V. (2016). Cultural Intelligence. Retrieved August 16, 2018, from http://www.linnvandyne.com/fourfac.html. Michigan State university, 16/05/2018.

Hadi Warsito., F. H. (2019). History of developtment and concept of person-centered counseling in cultural diversity. InternationalJournal Of Education Review , 4 (1), 56-64.

Koentjaraningrat. (2009). Pengantar Ilmu Anthropologi. Jakarta: Rineka CIpta.

Mareta, V. U. (2018). Pengembangan Bahan Ajar IPS Berbasis Folklore Lisan Untuk Meningkatkan Kecerdasan Budaya Siswa SMP. Surakarta: Sebelas Maret Univercity.

Roy, A. S. (2018). In heritage national Culture Through Learning in Elemantary School at Disruptive Era: Case study In Surakarta Indonesia. International Journal of Education Research Review , 3 (4), 48-58.

Suciani, L. (2017). Kecerdasan Budaya Mahasiswa Calon Konselor. Journal of Multicultural Studies in Guidance and Counseling , 1 (1), 139-148.

Suharli.(2017). Studi tentang kecerdasan budaya mahasiswa calon guru. Jurnal Unsa Progress , 22 (17).

Suw andi. (2011). Penelitian Tindakan Kelas. Surakarta:Univercity of Muhammadiyah Surakarta.

Widyarini. (2014). Retrieved from http://www .bppk.kemenkeu.go.id/publikasi/artikel/168-artikelpengembangan-sdm/20131-empat-faktor-kecerdasan-budaya-untuk-meningkatkan-keterampilaninterpersonal.

Zuchdi, D. (2008). Humanisasi pendidikan. Jakarta:Bumi aksara. 